Journal of Economics and Behavioral Studies

Vol. 6, No. 12, pp. 974-985, December 2014 (ISSN: 2220-6140)

\title{
Application of the Human Capital Life-Course Theory to Understand Generation Y South Africans' Money Attitudes
}

\author{
Helen I. Duh \\ University of Johannesburg (UJ), Auckland Park, Johannesburg, South Africa \\ duhhelen@yahoo.com
}

\begin{abstract}
The life-course approach is a current use of an interdisciplinary and a multi-theoretical framework to study how childhood experiences, especially family experience affect later-life attitudes and consumer behaviour. One childhood family experience believed to be strongly driving later-life attitudes and values, and studied under the human capital life-course theoretical perspective is family resources received during childhood. This study uses the human capital life-course theoretical perspective to study how family resources received during childhood affect later-life money attitudes of a large and lucrative market segment like Generation Y South Africans, especially as their money attitudes can influence varied consumer behaviour. Survey results from 826 subjects showed that they scored high in the security and budget money attitudes. Family resources received during childhood negatively impacted on their symbolic (status, achievement and worry) money attitudes and had a strong positive impact on their conservative (budget and security) money attitudes.
\end{abstract}

Keywords: Money attitudes; family resources; Generation Y; life-course theory; South Africa

\section{Introduction}

Organizational behaviour specialists, economic psychologists, sociologists and behavioural finance specialists are studying and categorizing people according to their money attitudes for various reasons. For example, organizational behaviour specialists profile employees' money attitudes to design and implement compensation systems and to understand job attitudes and action (Lim \& Teo, 1997). Behavioural finance specialists investigate people's money attitudes to assess the propensity to save (Medina, Saegert \& Gresham, 1996), to predict loan default tendencies (Sunil \& Kaushik, 2010) and stock investment interests (Keller \& Siegrist, 2006). Research on money attitudes in the marketing discipline is limited (Durvasula \& Lysonski, 2010), even though consumers' money attitudes can potentially influence a wide variety of consumer behavior (Rose \& Orr, 2007). Bonsu (2008) and Burgess (2007) suspect that outcomes of consumer behaviour like credit card abuse, compulsive buying behaviour, rising records of consumer debt and bankruptcy may emanate from high scorers of certain money attitude dimensions. Bonsu (2008) for example predicts that, high scorers of power-prestige money attitude may develop materialistic tendencies because of their belief that money can grant them access to power, status and success.

Changing money attitudes, from conservative to symbolic attitudes, according to Roberts and Jones (2001) are important catalysts behind the spread of consumer culture - a culture whereby consumers avidly desire, pursue, consume, and display possessions, as being important to their lives (Roberts \& Jones, 2001). The consequences of changing money attitudes can be more serious among Generation Y consumers, who have been raised with more access to credit, credit cards, many shopping channels, cable/digital TV, mobile phones and e-commerce (Bakewell \& Mitchell, 2003). Paul (2001) envisages that the biggest distinction between Generation Y and other Generations will be their attitude toward money. Since Gurney (1988) suggest that money attitudes begins in childhood, remains in adulthood, and influence later behaviours related to money, it will be important to use the life-course approach to investigate Generation Y's money attitudes.

The life-course approach provides an interdisciplinary and a multi-theoretical framework through which the effect of childhood experiences on later-life attitudes and consumer behaviour can be studied (Moschis, 2007). Childhood or past family and financial experiences may affect money attitudes, which may remain 
fairly consistent throughout one's life (Gurney, 1988; Lim \& Teo, 1997; Tang \& Gilbert, 1995). However, research is yet to be conducted on the mechanisms that link childhood family experiences to later-life money attitudes. Moschis (2007) suggest the use of three (stress, human capital, normative) life-course theoretical perspectives to study the impact of childhood family experiences on later-life consumer behaviour. Out of these three theoretical perspectives, Hill et al. (2001) view the human capital life-course theoretical perspective, in terms of family resources received during childhood as the most influential factor driving attitudes and behaviour, especially among young adults.

Young Adults, such as Generation Y, have been raised in an era of rapid political, technological innovations, economic and socio-cultural events and changes. One of the events whose effects are drawing the attention of consumer researchers, is the structural changes (e.g., double-digit increases in divorce rates, single-parent families and cohabitation) the family is undergoing. Unlike the previous generations that were raised mostly in intact two-parent families, one in four Generation Y children are being raised in single-parent/income family structures (Noble, Haytko \& Phillips, 2009), where they receive inadequate family resources, experience stress and economic hardship (Hill et al., 2001). According to Rindfleisch Burroughs and Dentton (1997), family resources (economic and emotional) received during childhood or before eighteenth birthday are part of the main factors that distinguish children raised in a well-off intact (two-parent) family structure from those raised in a poorer disrupted (single-parent) family structure.

In addition to the likelihood of growing up in a disrupted family structure, which may provide inadequate family resources, Generation Y also faces challenges of contributing to family income too early in life. They have also lived through the trauma of corporate downsizing, limited financial aid, and a weak job market (Wolburg \& Pokrywczynski, 2001). From these developments, the Marketing Science Institute made the study of Generation Y a research priority (Noble et al., 2009). More so, consumer researchers have questioned how changes in family structure and resultant family resources received are influencing Generation $Y$ attitudes and consumption values (Rindfleisch et al., 1997). In response, this study is aimed at examining the money attitudes of Generation Y South Africans, as well as using the human capital life-course theoretical perspective to understand the impact of childhood family structure and family resources received on Generation Y South Africans' money attitudes. Understanding Generation Y money attitudes is important because Generation Y is a large (about 37\% of South Africans fall within the 18-35 age group of Generation Y in 2012 - Statssa, 2011) and lucrative market segment, commonly reported to be born between 1977 and 1994 (Noble et al., 2009). Generation Y South Africans form majority (64\%) of the emerging middle class - known as 'Black Diamonds'. They contribute $40 \%$ of the R600 billion of Black Diamond spending power, and constitute a lucrative market for property, fashion accessories, entertainment products, cars, vacations, computers, electronics and mobile phones in South Africa (Kotler \& Armstrong, 2010).

In addition to the lucrative market potential of Generation Y South Africans, Denis (2006) reports that considerable number of the children born in the 1980s (birth years of Generation Y) were into disrupted single-parent family structures. It is therefore useful to not only examine the money attitudes of a large and lucrative market segment like Generation Y South Africans, but to also understand how childhood family structures and resultant family resources received affect their money attitudes. Previous researchers (see for example, Yamauchi \& Templer, 1982; Furnham, 1984; Rose \& Orr, 2007; and Baker \& Hagedorn, 2008) have focused on developing scales with which to measure various money attitudes dimensions. However, the investigation into the factors that shape or cause differences in money attitudes, especially among Generation Y has not received adequate attention. Reports from the US (Kimberly, 2010) and South Africa (Simpson, 2011) suggest that because of the 2008 recession, Generation Y have developed thrifty money attitudes. While Kimberly (2010) and Simpson (2011) are suggesting that economic recession has an impact on Generation Y money attitudes, this study makes a contribution by providing insights into how Generation Y money attitudes can be explained from human capital theoretical perspective (in terms of family structure and resources received during childhood or before eighteenth birthday). More so, retailers, bankers and consumer interest groups will be interested to know Generation Y South Africans' money attitudes as these can determine how easily they buy and bargain for products, save or invest money and how easily they can borrow and reliably make repayment of their debts (Keller \& Siegrist, 2006; Medina et al., 1996; Sunil \& Kaushik, 2010). 


\section{Literature Review}

This section defines money attitudes and examines the factors reported to be accounting for the differences in consumers' money attitudes. It starts by looking at the definition and dimensions of money attitudes. Even though there have been a number of studies on money attitudes, no clear definition of money attitudes has been found. According to Oleson (2004), it is difficult to provide a singular meaning of money attitudes because people's attitude toward money is diverse. Burgess (2007: 682) however defines money attitudes as "interpersonal, attitudinal [affective, behavioural, cognitive] beliefs that express [individual, collective, mixed] values concerned with money [independence....quality] and are evaluated in importance [very important to very unimportant] in order to guide behaviour within the context of money and money situations". For the purpose of this study, money attitude is simply defined as "the meanings, values, feelings and beliefs people attach to money". With the diverse meanings, values and beliefs people attach to money, clinical psychologists such as Yamauchi and Templer (1982) and Furnham (1984) have developed psychometricised questionnaires to measure the various dimensions of money attitudes. Yamauchi and Templer's (1982) money attitude scale (MAS) measures five dimensions (i.e., power/prestige, retention/time, quality, distrust and anxiety) while Furnham's (1984) money beliefs and behaviour (MBBS) scale measures six money attitude dimensions namely obsession, power/spending, retention, security/conservative, inadequate and effort/ability.

The most popularly used scale to measure money attitudes is Yamauchi and Templer's (1982) MAS because its cross-cultural testing produces higher and acceptable Cronbach internal reliability alphas (Burgess, 2007). Despite these merits, Rose and Orr (2007) noted that MAS was constructed using psychological approaches rather than a marketing-related design. Rose and Orr (2007) therefore developed a marketing-related scale, which they named as the money-motivation scale (MMS). It comprises the following five dimensions:

- $\quad$ Status -The tendency to perceive money as a sign of prestige. Money is used to impress people.

- Achievement - The tendency to perceive money as a symbol of one's accomplishments. Money is valued as a sign of success.

- Worry - The tendency to worry excessively about money. Money or the perceived lack thereof, is a source of anxiety.

- Security - The tendency to save and value money for its ability to provide a sense of safety or wellbeing. Money is important because it provides means for the future.

- Budget - The tendency to spend money wisely and cautiously.

Considering that MMS is more applicable to the field of marketing and consumer behaviour (Rose \& Orr, 2007), this study uses MMS to measure money attitudes. The next section discusses factors, which are reportedly affecting consumers' money attitudes. Investigations into the factors shaping or causing differences in people's money attitudes are limited. More so, most studies have focused on the demographic, cultural and ethnic characteristics accounting for the differences in money attitudes. The impact of age on money attitudes was of particular interest. Young people were consistently found to score low in retentiontime and security, and high in the power-prestige dimensions of money attitudes (Furnham, 1984; Baker \& Hagedorn, 2008; Bonsu, 2008). Gorniak (1999) asserts that inter-generational differences in values, life-styles and the stages in the life-cycle account for the age differences in money attitudes. The younger people are usually better educated and open to various economic and social lives. While older people hold greater fear about the future and a tendency to avoid additional risk factors like debts, younger people are more optimistic because they have longer employment potential. They thus have a greater tendency to borrow and spend money to improve their standard of living rather than to save it for the future (Gorniak, 1999).

Apart from the explanatory abilities of demographic characteristics, Furnham (1984) and Roberts Cesar and Sepulveda (1999) speculate that primary (parental financial practices and money habits) and secondary socializations (mass media) can also explain money attitudes. Past financial hardship (Lim \& Teo, 1997), perceived economic risk and social adjustment (Engelberg \& Sjoberg, 2007) are also reported as attributing to money attitudes variation. People who do not feel safe and are pessimistic about their economic future would have a lower propensity to save and a higher propensity to spend their money for power and to protect against anxiety (Gorniak, 1999). Other researchers see personality factors like introverts/extraverts (McClure, 1984), self-esteem (Hanley \& Wilhelm, 1992), needs (Oleson, 2004) and self-concept (low selfesteem, status seeking and jealousy - Prince, 1993) as the driving force behind varied money attitudes. 
Hanley and Wilhelm's (1992) findings show that compulsive spenders have beliefs about money which reflect their symbolic (achievement, status, recognition, respect, freedom and power) ability to enhance self-esteem. McClure (1984) found that extraverts have the tendency to be more extravagant and less stingy than introvert with money.

At the macro level, environmental factors such as societal norms (Zelizer, 1994), political and religious beliefs (Furnham \& Okamura, 1999) and cultural backgrounds (Gurney, 1988; Tang, 1993) affect the symbolic meanings people attach to money. Jain and Joy (1997) for example, report that Indians' cultural roots cause them to hold a long-term view (saving) of money. Indians need for saving, Jain and Joy (1997:647) state, "determines their consumption, and not the other way around". On the contrary, Mexican Americans were found to be less future-oriented as they scored lower on the retention-time money dimension (Medina et al., 1996). Mitchell and Mickel (1999) raise the issue about which money attitude dimensions are stable dispositions and which are more unstable attitudes. They suggest that money attitudes that are determined by personality factors and childhood experiences are more likely to be dispositional. Gurney (1988) and Tang and Gilbert (1995) support this viewpoint by suggesting that money attitudes established during childhood may remain fairly consistent throughout one's life.

Hypotheses Development from the Human Capital Life-course Theoretical Perspective on Money Attitudes: Moschis (2007:295) defines the life-course paradigm as an innovative and a multi-theoretical framework that integrates several approaches used in different disciplines (e.g., sociology, history, developmental psychology and economics) to study consumer behaviour over the course of people's lives. Life-course theorists view adult behaviours as a function of experiences (e.g., in socialisation, historical and generational times) at earlier stages of life. The life-course paradigm enriches previous efforts to study consumer behaviour through the use of the variables and relationships that are relevant to the main theoretical orientations of life-course research (Moschis, 2007). Previous studies have developed hypotheses from the human capital, normative and stress life-course theoretical perspectives, which suggest the sociopsychological factors linking family structure to materialistic values and compulsive buying behaviour (see for example, Benmoyal-Bouzaglo \& Moschis, 2009 and 2010; Moschis et al., 2013), but not for an important driver of behaviour like money attitudes. This study will examine how the human capital life-course theoretical perspective can be used to explain money attitudes.

The accumulation of human capital such as qualifications, skills, knowledge and other human and financial resources is seen as a life-course process that begins from early childhood. Life-course researchers are therefore investigating salient life events and settings, which act as sources of human capital growth or decline and are likely to bring about changes in patterns of thought and action (Frytak, Harley, \& Finch, 2003; Moschis, 2007). The family according to Frytak et al. (2003) is a source of human capital. A reduction in financial resources due to family disruption (e.g., parental divorce or separation) adversely affects children's ability to accumulate human capital, such as the educational attainment necessary for achieving higher occupational status and wealth. This, Moschis (2007) suggest, may later lead to lower income status, affect self-esteem, which Hanley and Wilhelm (1992) found may be enhanced through the belief of money's ability to provide power and security. Conceptualizing the human capital perspective in terms of economic hardship theory, Hill et al. (2001) point out that, single-parent families tend to have lower incomes than two-parent families. Inequalities in family resources Rindfleisch et al. (1997) report, place children from non-intact single-parent family structure at an inherent disadvantage position compared to children raised in intact twoparent family structure. This, they continue, may affect their life chances (for instance educational attainment) and self-esteem.

Gorniak's (1999) study on attitudes towards money and saving show that those who had lower education and income frequently accepted the statement: "people who save money don't know how to enjoy life" (Gorniak, 1999:635). Apart from the fact that lower educated and income people turn to have less money, they may have less know-how and more anxiety about using money. They may thus not know how to budget the use of their money, be less cautious in spending money (Gorniak, 1999), or may develop symbolic money attitudes, such as power, achievement, success and status later in adulthood (Hanley \& Wilhelm, 1992). From these, the following hypotheses, as presented in Figure 1, can be formulated: 


\section{Figure 1: The conceptual model of the study}

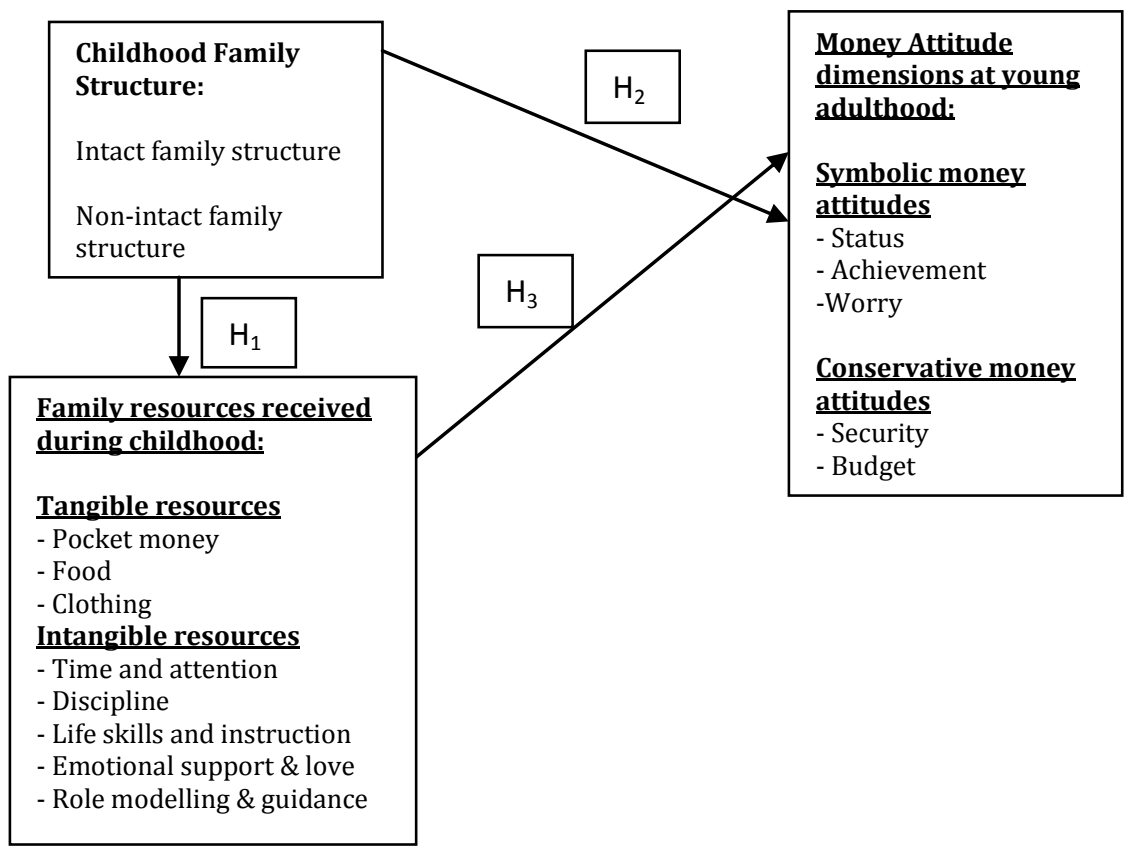

Source: Researcher's model developed from Moschis' (2007:297) life-course model of consumer behaviour

$\mathrm{H}_{1}$ There would be a significant difference in family resources received during childhood among Generation Y South Africans raised in non-intact and intact family structures.

$\mathrm{H}_{2}$ There would be a significant difference in money attitude dimensions among Generation Y South Africans raised in non-intact and intact family structures.

$\mathrm{H}_{3}$ There is a positive relationship between family resources received during childhood and later-life conservative (security and budget) money attitudes; and (b) negative relationship between family resources received during childhood and later-life symbolic (status, achievement, worry) money attitudes of Generation Y South Africans.

\section{Methodology}

Data collection method: Considering this study's objectives and the nature of the research problems, quantitative research methods were used to collect data. Scales developed and tested for validity and reliability by previous researchers (e.g., Rindfleisch et al., 1997, Rose \& Orr, 2007) were used to measure the main variables (i.e., childhood family structures, family resources received during childhood and money attitudes) of this study. Considering that students' email addresses were accessible, an online survey was used to collect data. Online surveys guarantee the respondents' anonymity, and they could honestly answer the questions at their most convenient time and day.

Samples: The data was collected from university-aged (18-25 years) Generation Y South Africans, who were business undergraduate students from Nelson Mandela Metropolitan University (NMMU) and the University of the Western Cape (UWC) in Cape Town. Business students were surveyed because Martin and Turley (2004) find them suitable to respond to consumer behaviour surveys. Obtaining email addresses from class registers, students were sent e-mails to participate in the online survey.UWC is situated in Cape Town of South Africa, where a considerable number of young South Africans from diverse socio-economic and ethnic backgrounds are found. NMMU is in Port Elizabeth of the Eastern Cape of South Africa where according to Siqwana-Ndulo (1998), there are a high percentage of single-parent households. The students from both universities e-mailed to participate in the study were 1276, of which 826 fully completed responses were received. The response rate was therefore $64.7 \%$. There were $52.1 \%$ and $47.9 \%$ female and male respondents respectively. Compared to $52.2 \%$ subjects who grew up in a two-parent family structure, up to $48.8 \%$ were 
raised in single-parent families. Respondents who grew up in financially well-off households were 58.4\%, as opposed to $41.4 \%$ who lived in households that were not financially well-off before their $18^{\text {th }}$ birthday. More mother-only (26.9\%) provided household income than father-only $(17.7 \%)$ homes. Family experiences before 18th birthday were considered, because Chase-Lansdale et al. (1995) report that family events experienced when subjects are adolescence (12 - 18 years) are more impactful on later behaviours, especially as self-worth and identities are being formed at this stage of life.

Measures: Even though the scales used for this study had been previously used and proven valid and reliable, their reliability was tested again with Generation Y South Africans. The results showed that all the scales produced good reliability alphas. In line with Rindfleisch et al. (1997), childhood family structure was viewed in terms whether it was "intact" and "non-intact", and measured in terms of whether respondents did or did not live with both their biological parents before their $18^{\text {th }}$ birthday respectively. Respondents had to answer this question with a 'yes' or 'no'. Equally using Rindfleish et al. (1997) measurement scale, family resources received during childhood were measured in terms of respondents' ratings on how economic resources (food, clothing, pocket money) and emotional resources (practical help, love, emotional support, role modeling and guidance) received before $18^{\text {th }}$ birthday were perceived to be exceptional or inadequate. Five-point Likert scale with 1 = inadequate support, and 5 = exceptional support was used to measure the eight-item scale. Money attitudes were measured in terms of how subjects agreed or disagreed to Rose and Orr's (2007) twenty four-item money-attitude scale. Five-point Likert scale was used with $1=$ strongly disagree, and $5=$ strongly agree. The reliability coefficients obtained for the family resources and money attitudes scales are presented in Table 1.

Data analyses methods: Wilcoxon Rank Sum Test, a non-parametric statistics was used to test if there were significant differences in family resources received during childhood and money attitudes among subjects raised in non-intact (NI) and intact (I) family structures. Non-parametric statistics was appropriate because an examination of plots of the scores showed that the distribution was skewed as opposed to them being a normal distribution. Regression analyses were used to examine the impact of childhood family resources received on money attitudes at young adulthood.

\section{Results}

Descriptive statistics: The descriptive statistics of the main variables and their dimensions are presented in Table 1.

Table 1: The mean, standard deviation and reliability of variables and their dimensions

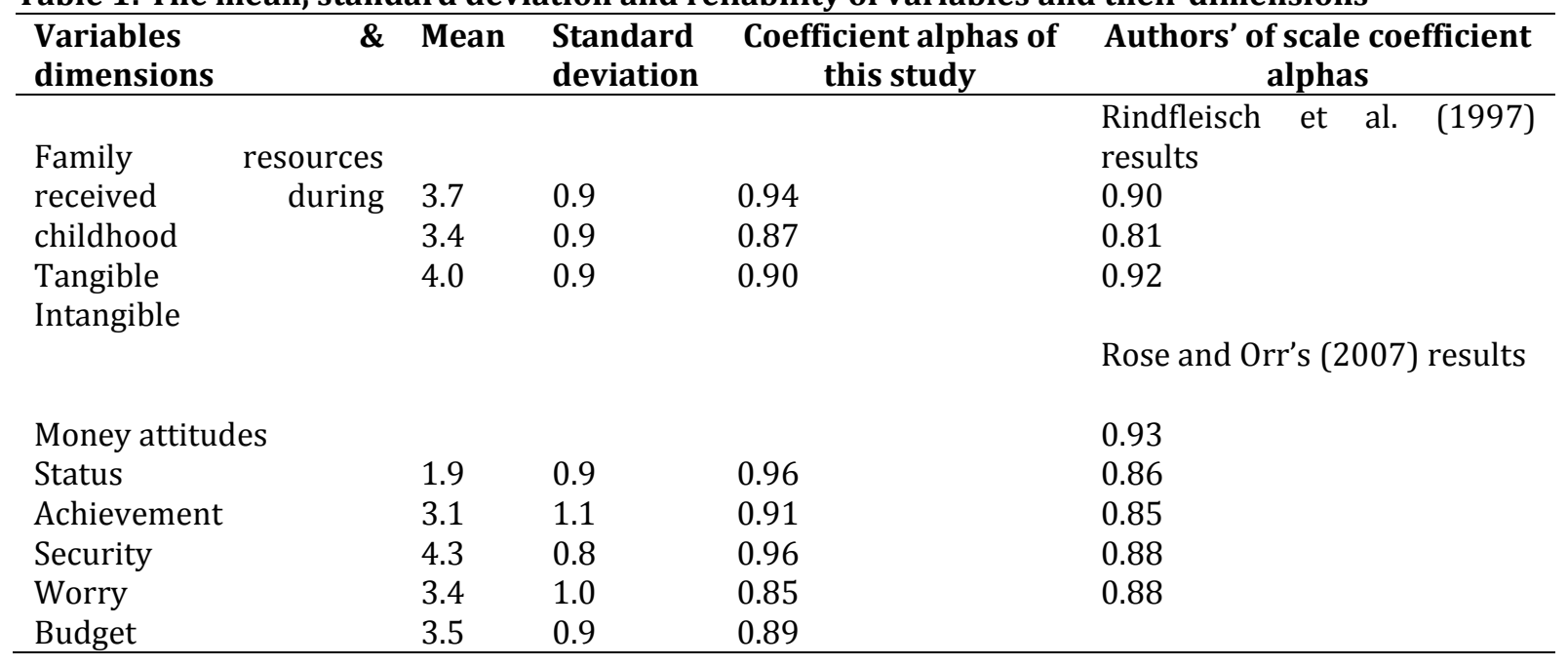

Table 1 shows that, all the scales and their dimensions possessed adequate and above threshold (0.70) reliability. The mean scores of the variables indicate that overall, Generation Y South Africans surveyed viewed family resources received from parents during childhood as moderately $(M=3.7)$ adequate. 
Specifically, emotional resources (e.g., love, guidance and emotional support) received from parents during childhood were perceived to be higher $(M=4.0)$ than the economic resources (food, clothing and pocket money) $(M=3.4)$. In terms of money attitudes, the mean rating for security $(M=4.3)$ was the highest, budget $(M=3.5)$ was second highest, and worry $(M=3.4)$ was the third highest. Another important descriptive statistics conducted for this study is a confirmatory factor analysis (CFA) to confirm among Generation Y South Africans, the Rose and Orr's (2007) five-factor solution obtained in the US. The results are found in Table 2.

Table 2: Money attitude dimensions obtained from Rose and Orr's (2007) scale

Money attitudes dimensions and items

Factor 1 Budget (items 19-23)*

I budget my money very well.

I spend my money wisely.

I spend my money very carefully.

I am proud of my ability to save money.

I believe in being careful on how I spend my money.

Factor 2 Security (items 10-14)

Saving money gives me a sense of security.

It is very important for me to save money for the future.

Doing financial planning for the future provides me a sense of security.

I prefer to save money because I am never sure when things will collapse and I might need the cash.

It is very important for me to save enough to provide well for my family in the future.

Factor 3 Achievement (items 5-9)

Money is a symbol of success.

I value money very highly as a sign of success.

A high income is an indicator of competence.

Money represents one's achievement.

I believe that the amount of money that a person earns is closely related to his/her

ability.

Factor 4 Status (items 1-4)

I must admit that I purchase things because I know they will impress others.

CFA

factor loading

I sometimes buy things that I do not need or want in order to impress people.

0.92

0.92

0.87

0.80

0.67

I own nice things in order to impress others.

0.91

0.91

0.77

0.77

I sometimes "buy" friendship by being very generous with those I want to like me. $\quad 0.55$

Factor 5 Worry (items 15-18)

I worry a lot about money.

0.73

I worry about not being able to make ends meet.

0.85

I worry about losing all my savings.

0.82

The amount of money I save is never quite enough.

0.78

0.69

Total variance explained

$68 \%$

*Item 24 loading (.20) was less than .40 and was thus deleted from factor 1.

Table 2 show that Rose and Orr's (2007) five-factor solution for money attitudes were confirmed in this study with a $68 \%$ of total variance explained.

Inferential statistical results: Hypothesis $1\left(\mathrm{H}_{1}\right)$ posited that there would be a significant difference in family resources received during childhood among Generation Y South Africans raised in non-intact (NI) and intact (I) family structures. Table 3 provides the result of $\mathrm{H}_{1}$. 
Table 3: Differences in family resources received between non-intact/intact families

\begin{tabular}{|c|c|c|c|c|c|c|c|}
\hline $\begin{array}{l}\text { Family } \\
\text { structure }\end{array}$ & Observation & Variable & $\mathbf{N}$ & Mean & Median & $\begin{array}{l}\text { Std } \\
\text { Deviation }\end{array}$ & P-value \\
\hline $\mathrm{NI}$ & 345 & economic & 343 & 3.2 & 3.0 & 0.94 & \\
\hline I & 481 & economic & 479 & 3.6 & 3.7 & 0.88 & $<0.0001^{* *}$ \\
\hline $\mathrm{NI}$ & & emotional & 343 & 3.8 & 4.0 & 0.93 & \\
\hline I & & emotional & 479 & 4.1 & 4.2 & 0.79 & $<0.0001^{* *}$ \\
\hline
\end{tabular}

According to the mean levels outlined in Table 3 of family resources received during childhood, subjects who grew up in non-intact homes reported lower levels of economic (non-intact $M=3.2$, intact $M=3.6$ ) as well as emotional (non-intact $M=3.8$, intact $M=4.1$ ) resources. The differences were significant ( $\mathrm{p}<0.0001)$ at $99 \%$ confidence level. This result supports $\mathrm{H}_{1}$ and is in line with Rindfleisch et al.'s (1997) finding that revealed that young adult Americans who were raised in non-intact families received significantly lower levels of family resources (non-intact $M=3.24$, intact $M=3.97$ ) than those raised in intact families.

Table 4: Differences in money attitudes between non-intact/intact families

\begin{tabular}{llllllll}
\hline $\begin{array}{l}\text { Family } \\
\text { structure }\end{array}$ & Observation & Variable & N & Mean & Median & $\begin{array}{l}\text { Std } \\
\text { Deviation }\end{array}$ & P-value \\
\hline NI & 345 & Status & 340 & 1.9 & 1.5 & 0.92 & 0.50 \\
& & Achievement & 340 & 3.0 & 3.0 & 1.11 & 0.94 \\
& Security & 340 & 4.2 & 4.6 & 0.90 & 0.42 \\
& Worry & 337 & 3.5 & 3.6 & 1.00 & $0.03^{*}$ \\
& Budget & 340 & 3.4 & 3.5 & 0.90 & 0.22 \\
I & & & & & & \\
& & Status & 479 & 1.9 & 1.8 & 0.89 & 0.50 \\
& \multirow{2}{*}{481} & Achievement & 479 & 3.0 & 3.0 & 1.02 & 0.94 \\
& Security & 479 & 4.3 & 4.6 & 0.78 & 0.42 \\
& Worry & 479 & 3.3 & 3.3 & 1.02 & $0.03^{*}$ \\
& Budget & 477 & 3.5 & 3.5 & 0.87 & 0.22 \\
\hline
\end{tabular}

${ }^{*}=$ statistically significant at $95 \%$ confidence level

For Hypothesis $2\left(\mathrm{H}_{2}\right)$ it was expected that there would be a significant difference in the various money attitude dimensions among Generation Y South Africans raised in non-intact and intact family structures. Table 4 shows that the only significant difference (even though marginal) in money attitude dimensions between subjects raised in non-intact and intact family structures is in the worry money attitude dimensions (non-intact $M=3.6$, intact $M=3.3$ ). This means that subjects raised in non-intact family structure are obviously more anxious about their finances and ability to make ends meet (Rose \& Orr, 2007). Hypothesis 3 $\left(\mathrm{H}_{3}\right)$ suggested that there would be positive relationships between family resources received during childhood and later-life conservative (security and budget) money attitudes; and a negative relationships between family resources received during childhood and later-life symbolic (status, achievement, worry) money attitudes. Table 5 presents the regression results of $\mathrm{H}_{3}$. From the results in Table $5, \mathrm{H}_{3}$ (a) and $\mathrm{H}_{3}$ (b) are all supported. This depicts that a decrease in family resources received during childhood will increase the development of symbolic (status, achievement, worry) money attitudes during young adulthood; and an increase in family resources received during childhood will increase the likelihood of adopting conservative (security and budget) money attitudes at young adulthood. 
Table 5: Regression analyses results

\begin{tabular}{lllll}
\hline Independent variables & Dependent variables & $\begin{array}{l}\text { Beta } \\
\text { coefficients }\end{array}$ & P-values & F-value \\
\hline $\begin{array}{lllll}\text { Family resources received during } \\
\text { childhood }\end{array}$ & Money attitudes & & & \\
& Status & -0.09 & $0.016^{*}$ & 5.86 \\
& Achievement & -0.08 & $0.040^{*}$ & 4.24 \\
& Worry & -0.15 & $0.0001^{* *}$ & 16.61 \\
& Security & 0.15 & $0.0001^{* *}$ & 15.38 \\
& Budget & 0.10 & $0.012^{* *}$ & 6.41 \\
\hline
\end{tabular}

${ }^{*}=$ statistically significant at $95 \%$ confidence level

${ }^{* *}=$ statistically significant at $99 \%$ confidence level

Discussion: In addition to examining the money attitudes of Generation Y South Africans, this study used Generation Y South Africans to understand how the human capital life-course theoretical perspective can explain money attitudes. This was done by looking at the impact of childhood family structure and family resources received during childhood on later-life money attitudes. In terms of the money attitudes Generation Y South Africans have adopted (objective 1 of this study), the security $(M=4.3)$ and budget $(M=3.5)$ money attitudes were the most dominant dimensions. Yamauchi and Templer (1982) see the security and budget money attitudes as a retention-time money attitude. Interestingly, Rousseau and Venter (1999), Burgess (2005) and Burgess et al. (2005) had used Yamauchi and Templer's (1982) MAS to survey older South Africans and they successively found that the subjects scored higher in the retentive money attitude. People with this attitude believe that money should be saved for the future through purposeful planning. They would thus carefully spend money to get a sense of security. As it is in the case of this study, Rose and Orr (2007) used the money motivation scale (MMS) and found that Generation Y students in the US scored high in the retentive money attitude. The result in South Africa is in contract with those found in other emerging economies such as Ghana, India and China. Like Bonsu (2008) and Sunil and Kaushik (2010), who found high scores in the power/prestige and anxiety/worry money attitudes in Ghana and India respectively among professionals, Durvasula and Lysonski (2010) found that young Chinese consumers scored high in the power/prestige and anxiety/worry money attitudes. In India, Sunil and Kaushik (2010) found that high scorers of anxiety/worry money attitude were more likely to default on bank loan repayments and in China, this money attitude was a strong driver of young Chinese consumers' materialistic values.

Durvasula and Lysonski (2010) speculated that because of growing industrialization and modernization in emerging markets, its consumers will develop symbolic money attitudes (power/prestige, achievement and status) as found in India and China. The conservative (security and budget) money attitudes found in South Africa is however, an indication that not all emerging market consumers will develop symbolic money attitudes. Scoring high in the conservative money attitudes also raises a question as to why savings rates in South Africa are low and debt levels are very high (De Waal, 2013). The main findings from the hypothesized relationships (objective 2 of this study) portray that there is a significant difference in family resources received during childhood between subjects raised in non-intact and intact family structures. Compared to those raised in intact family structure, the respondents, who grew up in non-intact family structure significantly scored higher in worry money attitude. This finding supports Gorniak's (1999) view that children from socio-economically disadvantaged backgrounds are more likely to develop anxiety/worry money attitudes because they may have less money know-how and become more anxious about using money. Cohen and Cohen (1996) further suggest that because of lower family resources received (economic and emotional) children from socio-economically disadvantaged homes may more likely concern themselves with materialistic values based on emotional insecurity and a desire to impress others.

In this study, family resources received during childhood impacted positively on conservative (security and budget) money attitudes and negatively on symbolic (status, achievement, worry) money attitudes at young adulthood. The results imply that if Generation Y South Africans received less family resources from parents when growing up, they will more likely worry about money matters and view money as symbols of status and achievement. Conversely, if they received more family resources from parents when growing up, they would more likely adopt security (money should be saved for the future) and budget (money should be spent cautiously) attitudes toward money. Unlike Lim and Teo (1997), who found that past financial hardship 
caused Generation Y Singapore students to develop achievement money attitudes and to be more generous to those less fortunate, this study show that there is a negative relationship between achievement money attitude and childhood family resources received; and a positive relationship between retentive/conservative money attitudes and childhood family resources received among Generation Y South African students. Generally however, this study's findings support Lim and Teo's (1997) and Roberts et al. (1999) proposal that past experiences impact on later-life money attitudes.

\section{Managerial Implications and Recommendations}

In addition to the empirical uncovering of how childhood family structure and family resources received during childhood affect later-life money attitudes, the prominence of the conservative (security and budget) money attitudes among this study's sample is remarkable. Kimberly (2010:29) also found that US Generation Y consumers have security and budget money attitudes to the point that, they would "research their purchase decisions, and are more interested in saving money" because they have so much access to the Internet and other sources of information on products and various price offerings. Even with a qualitative study, Noble et al. (2009) found that majority of Generation Y Americans interviewed search the Internet for the lowest price or value-for-money. When they find it, they feel a sense of accomplishment. Kimberly (2010) in the US and Simpson (2011) in South Africa are interpreting this cautious attitude towards spending (i.e., budget money attitude) from the recent economic recession. Noble et al. (2009) suspect that, this attitude is the result of most Generation $\mathrm{Y}$ experiences in single-parent and single-income families. According to Wolburg and Pokrywczynski (2001), Generation Y does not only have to contribute to family finances at a very early age, they also have to cope in a weak job market. Irrespective of the forces behind Generation Y's conservative money attitudes, Kimberly (2010) and Simpson (2011) predict that the culture of thrift among Generation Y may become a permanent phenomenon.

Consumer interest authorities, retailers and banks will be interested in this finding. While banks would want to harness Generation Y tendency to save for the future, and consumer interest authorities would want to promote their desire to cautiously spend money, these would have serious implications for retailers and other companies who would have to provide value for money to capture and retain this large and lucrative consumer segment. To take advantage of the size of Generation Y consumers and their love for shopping however, marketing managers would have to find innovative ways of cutting cost and staying efficient. For human resource managers, Rose and Orr (2007) recommend that when dealing with Generation Y, who are high scorers in security and worry money attitudes, the managers should revise various types of compensation, retirement, and benefits packages, because these young adult employees would not only place a high value on comprehensive benefits and retirement packages, but would also shun variable forms of compensation, such as commissions, bonuses, or incentives.

Finding that inadequate family resources received during childhood (especially intangible or emotional resources of love, role modelling and attention) do affect US young adults' materialistic tendencies negatively, Rindfleisch et al. (1997) recommended that public policy measures should be put into place to guarantee that children get adequate family resources when growing up. French civil code, for example, puts an obligation on parents to provide not only for the financial and educational development of their children (including those adopted and those born out of wedlock), but also moral support (Xanthaki, 2000). Family resources received during childhood as seen in Table 5 strongly and positively affected conservative money attitudes of security and budget. This means that when children grow up feeling they were loved and provided adequate economic and emotional support, they would tend to save money for the future (security money attitude) and spend their money cautiously (budget money attitude) as opposed to developing symbolic money attitudes. This result suggests that in addition to the National Credit Act's efforts to curb consumers' huge and rising debt in South Africa, there should be public policy measures that put some obligations on parents to provide their children with adequate economic and emotional family resources. Rindfleisch et al. (1997) contend that emotional family resources such love, attention, and affection are important prerequisite for happiness, and according to Guven (2012), happier people tend to save more for the future and plan their spending better because they expect longer life. 


\section{Reference}

Baker, P. M. \& Hagedorn, R. B. (2008). Attitudes to money in a random sample of adults: Factor analysis of the MAS and MBBS scales, and correlations with demographic variables. The Journal of Socio-Economics, 37, 1803-1814.

Bakewell, C. \& Mitchell, V. (2003). Generation Y female consumer decision-making styles. International Journal of Retail \& Distribution Management, 31(2), 95-106.

Benmoyal-Bouzaglo, S. \& Moschis, G. P. (2009). The effects of family structure and socialization influences on compulsive consumption: a life-course study in France. International Journal of Consumer Studies, $33,49-57$.

Benmoyal-Bouzaglo, S. \& Moschis, G. P. (2010). Effects of Family Structure and Socialization on Materialism: A life Course Study in France. Journal of Marketing Theory and Practice, 18(1), 55-71.

Bonsu, S. K. (2008). Ghanaian attitudes towards money in consumer culture. International Journal of Consumer Studies, 32,171-178

Burgess, S. M. (2005). The importance and motivational content of money attitudes: South Africans with living standards similar to those in industrialised Western countries. South African Journal of Psychology, 35(1), 106-126.

Burgess, S. M. (2007). Toward a Theory on the Content and Structure of Money Attitudes. Advances in Consumer Research, 32, 682-683.

Burgess, S. M., Battersby, N., Gebhardt, L. \& Steven, A. (2005). Money Attitudes and Innovative Consumer Behaviour: Hedge Funds in South Africa. Advances in Consumer Research, 32, 315-321.

Chase-Lansdale, P. L., Cherlin, A. J. \& Kierman, K. E. (1995). The Long-term Effects of Parental Divorce on Mental Health of Young Adults: A Developmental Perspective. Child Development, 66, 1614-1634.

Cohen, P. \& Cohen, J. (1996). Life values and adolescent mental health, Mahwah, NJ: Lawrence Erlbaun.

De Waal, M. (2013). South Africans are sinking under debt - and the credit amendment bill won't pull us out. Daily Maverick, 04 June. Available from: http://www.dailymaverick.co.za/article/2013-06-04south-africans-are-sinking-under-debt-and-the-credit-amendment-bill-wont-pull-usout/\#.UiLTFWucH_Q (Accessed 31 August 2013).

Durvasula, S. \& Lysonski, S. (2010). Money, money, money - how do attitudes toward money impact vanity and materialism? The case of young Chinese consumers Journal of Consumer Marketing, 27(2), 169179.

Engelberg, E. \& Sjoberg, L. (2007). Money obsession, social adjustment, and economic risk perception. The Journal of Socio-Economics, 36, 686-69.

Frytak, J., Harley, C. R. \& Finch, M. D. (2003). Socio-economic status and health over the life course. In Handbook of the Life Course (Ed. By H.T. Mortimer \& M.J. Shanahan), Plenum Publishers, New York, 623-643

Furnham, A. (1984). Many sides of the coin: The psychology of money usage. Personal and Individual Differences, 5, 501-509.

Furnham, A. \& Okamura, R. (1999). Your Money or Your Life: Behavioural and Emotional Predictors of Money Pathology. Human Relations, 54(9), 1157-1177.

Gorniak, J. (1999). Attitudes towards Money and Dealing with Money: Selected Results of the Research in Poland. Innovation, 12(4), 633-645.

Gurney, K. (1988). Your money personality. New York: Doubleday.

Guven, C. (2012). Reversing the question: does happiness affect consumption and savings behaviour? Journal of Economic Psychology 33(4), 701-717.

Hanley, A. \& Wilhelm, M.S. (1992). Compulsive buying: An exploration into self-esteem and money attitudes. Journal of Economic Psychology, 13, 5-18.

Hill, M. S., Yeung, W. J. J. \& Duncan, G. J. (2001). Childhood family structure and young adult behaviours. Journal of Population Economics, 14, 271-299.

Jain, A. K. \& Joy, A. (1997). Money matters: An exploratory study of the socio-cultural context of consumption, saving, and investment patterns. Journal of Economic Psychology, 18, 649-675.

Keller, C. \& Siegrist, M. (2006). Money Attitude Typology and Stock Investment. The Journal of Behavioural Finance, 7(2), 88-96.

Kimberly, P. (2010). Talking to Gen Y about the New Culture of Thrift. U.S. News \& World Report, March 2010, $147(3), 29-32$. 
Kotler, P. \& Armstrong, G. (2010). Global and Southern African Perspectives in Principles of Marketing. $1^{\text {st }}$ ed. South Africa: Pearson Hall.

Lim, V. K. G. \& Teo, T. S. H. (1997). Sex, financial hardship, and locus of control: an empirical study of attitudes towards money among Singaporean Chinese. Journal of Economic Psychology, 18, 369-386.

Martin, C. A. \& Turley, L. W. (2004). Malls and Consumption motivation: an exploratory examination of older Generation Y consumers. International Journal of Retail \& Distribution Management, 32(10), 464475.

McClure, R. F. (1984). The relationship between money attitudes and over-all pathology. Psychology: $A$ Quarterly Journal of Human Behaviour, 21, 4-6.

Medina, J. F., Saegert, J. \& Gresham, A. (1996). Comparison of Mexican-American and Anglo American attitudes toward money. The Journal of Consumer Affairs, 30(1), 124-144.

Mitchell, T. R. \& Mickel, A. E. (1999). The Meaning of Money: An Individual Difference Perspective. Academy of Management Review, 24(3), 568-578.

Moschis, G. P. (2007). Life-course perspectives on consumer behaviour. Journal of the Academy of Marketing Science, 35, 295-307.

Moschis, G. P., Mathur, A., Kwai, C. F. \& Pizzutti, C. (2013). Effects of Family Structure on Materialism and Compulsive Consumption: A Life Course Study in Brazil. Journal of Research for Consumers, 23, 6696.

Noble, S. M., Haytko, D. L. \& Phillips, J. (2009). What drives college Generation Y consumers? Journal of Business Research, 62, 617-628.

Oleson, M. (2004). Exploring the relationship between money attitudes and Maslow's hierarchy of needs. International Journal of Consumer Studies, 28(1), 83-92.

Paul, P. (2001). Getting Inside Gen Y. American Demographics, 23(9), 42-50.

Prince, M. (1993). Self-concept, money beliefs and values. Journal of Economic Psychology, 14, 161-173.

Rindfleisch, A., Burroughs, J. E. \& Denton, F. (1997). Family structure, materialism and compulsive consumption. Journal of Consumer Research, 23, 312-325.

Roberts, J. A. \& Jones, E. (2001). Money attitudes, credit card use, and compulsive buying among American college students. Journal of Consumer Affairs, 35(2), 213-240.

Roberts, J. A., Cesar, J. \& Sepulveda, M. (1999). Demographics and money attitudes: a test of Yamuachi \& Templer's (1982) money attitude scale in Mexico. Personality and Individual Differences, 27, 19-35.

Rose, G. M. \& Orr, L. M. (2007). Measuring and Exploring Symbolic Money Meanings. Psychology \& Marketing, 24(9), 743-761.

Rousseau, G. G. \& Venter, D. J. L. (1999). Measuring Consumer Attitudes toward Money. South African Journal of Economic and Management Studies, 2(3), 407-422.

Simpson, J. (2011). Recession's aftermath still haunts SA consumers - UCT Unilever study finds. Accessed from: http://www.bizcommunity.com/PressOffice/PressRelease.aspx?i=114337\&ai=59131 (Accessed 04 August 2011).

Siqwana-Ndulo, N. (1998). Rural African family structure in the Eastern Cape Province, South Africa. Journal of Comparative Family Studies, 29(2), 407-417.

Statistics South Africa. (2011). Distribution of total population by age groups and sex. Accessed from: http://mobi.statssa.gov.za/census2011/Age.html Accessed 31 March 2014).

Sunil, B. \& Kaushik, B. (2010). Modelling Money Attitudes to Predict Loan Default. The IUP Journal of Bank Management, $9(1 \& 2), 12-20$.

Tang, T. L. P. \& Gilbert, P. R. (1995). Attitudes toward money as related to intrinsic and extrinsic job satisfaction, stress and work related attitudes. Personality and Individual Differences, 19, 327-332.

Tang, T. L. P. (1993). The meaning of money: Extension and exploration of the money ethic scale in a sample of university students in Taiwan. Journal of Organizational Behaviour, 14, 93-99.

Wolburg, J. M. \& Pokrywczynski, J. (2001). A Psychographic Analysis of Generation Y College Students. Journal of Advertising Research, September/October, 33-50.

Xanthaki, H. (2000). The judiciary-based system of child support in Germany, France and Greece: an effective suggestion. Journal of Social Welfare and Family law, 22(3), 295-311.

Yamauchi, K. \& Templer, D. (1982). The development of a money attitude scale. Journal of Personality Assessment, 46, 522-528.

Zelizer, V. A. (1994). The social meaning of money. New York: Basic Books. 